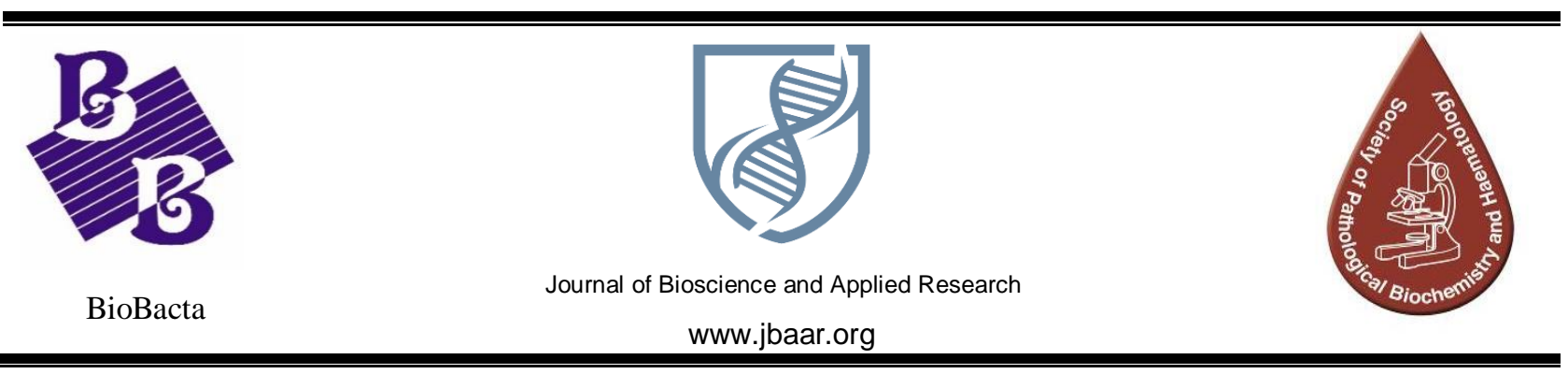

\title{
Ultrastructure of spermatogenesis and gonad somatic cells of a hermaphrodite gland of Eobania vermiculata (Gastropoda: Pulmonata) Müller, 1774 in Egypt
}

\author{
MostafaYahia Morad \\ Zoology and Entomology Department, Faculty of Science, Helwan University, Egypt \\ E-mail: Mustafa_ali@sceince.helwan.edu.eg. \\ DOI: 10.21608/jbaar.2021.175860
}

\begin{abstract}
:
The spermatogenesis of adult snail Eobania vermiculata was investigated using transmission electron microscope (TEM) studies. The hermaphrodite gland (ovotestis) is composed of many lobes which have numerous acini. Each acinus was filled with many stages of spermatogenesis and one or more oocytes. The oocytes were usually separated from the rest of the acinus by follicle cells. Spermatogenesis is divided into 5 stages; spermatogonia, primary spermatocytes, secondary spermatocytes, spermatids, and spermatozoa. The gonadal somatic cells; Sertoli cells are divided into two types, cortical Sertoli cells, and luminal Sertoli cells.
\end{abstract}

KEYWORDS: spermatogenesis, Sertoli cells, follicle cells, tunneling nanotubes, hermaphrodite gland.

\section{Introduction:}

The pulmonate molluscs are usually hermaphrodites and their gonad is termed an ovotestis or hermaphrodite gland (Heller, 1990, 2001; Roy et al., 2019). The ovotestis is composed of many acini in which both male and female gametes are formed (Luchtel, 1972a, b; Jong- Brink et al., 1976; Rakshit et al., 2005; Roy et al., 2018, 2019).

Spermatogenesis and the morphology of sperm are widely used in phylogenetic and evolutionary reconstructions as these studies are usually taxonspecific and provide comparative characters for species (Hodgson, Healy, 1988; Franco et al., 2008; Chen et al., 2015). Although great attention was paid to the reproductive cycle of some pulmonates (Nanaware, Gonjari, 1989; Wang et al., 2006; Chen et al., 2010), few studies have focused on ultrastructural changes during spermatogenesis (Griffond et al., 1990).

Received: April 3, 2021. Accepted: June 1, 2021. Published: June 6, 2021
Eobania vermiculata (Müller, 1774) is a terrestrial stylommatophoran snail (Pulmonata: Helicidae). It is hermaphrodite and usually inhabits fields, gardens, crops, and vineyards. In Egypt, this snail is one of the most common species and is becoming a serious agricultural pest to several vegetations including orchard trees, vegetable crops as well as ornamental plants, causing considerable damage to all plant parts (Mohamed, Ali, 2009). There's a need to offer methods that may help in decreasing their economic effects and these methods should be in line with basic research as reproductive biology. The ovotestis of $E$. vermiculata is slightly embedded in the digestive gland as in other pulmonates (Quatrini, Lanza, 1964; Kulkarni, 1973) while it is represented as a completely separated globular mass in Onchidium (Bing et al., 2008). Although many investigations have studied the reproductive biology aspects of Eobania vermiculata which included Mating, 
oviposition, post-oviposition period, development, and generation period (Mohamed, Ali, 2009), few studies concerned with the fine structure of spermatogenesis.

The specific aims of this study are to show ultrastructure stages of spermatogenesis as the main aspect of the reproductive biology of E.vermiculata and to help in clarifying phylogenetic analyses among the Pulmonata.

\section{Materials and methods:}

A total of 20 adult specimens of Eobania vermiculata were collected from the gardens and fields found in Giza Governorate, Egypt during the winter season, 2020. For transmission electron microscopy (TEM), first small fragments of the hermaphrodite gland were fixed for $3 \mathrm{~h}$ in $2.5 \%$ glutaraldehyde in $0.2 \mathrm{M}$ sodium cacodylate buffer ( $\mathrm{pH} 7.4$ ) at $4^{\circ} \mathrm{C}$ then washed in the same buffer for $2-4 \mathrm{~h}$ at $4^{\circ} \mathrm{C}$ and postfixed in $1 \%$ $\mathrm{OsO}_{4}$ solution in $0.2 \mathrm{M}$ phosphate buffer ( $\mathrm{pH}$ 7.4) for $2 \mathrm{~h}$ at the same temperature. Tissues were dehydrated through a graded series of ethanol concentrations (70\%, 80\%, 90\%, 95\%, and 2 changes of absolute ethanol) and embedded in Epon-Araldite mixture. Semithin sections were stained by methylene blue and observed by a light microscope. Ultrathin sections were cut with a diamond knife (RMC Poeckler) then stained with uranyl acetate and lead citrate and observed by a JEOL100CX-II TEM operated at $80 \mathrm{Kv}$ at the central laboratory in the Faculty of Science, Ain Shams University, Egypt.

\section{Results:}

The hermaphrodite gland of E. vermiculata contains many lobes; each of which includes numerous acini. The acini are elongated to semicircular and they have a homogeneous matrix and a lumen at the center characterized by the presence of spermatids and sperms (Fig. 1A-C). It was noted that each acinus contains one large oocyte peripherally located on the epidermal acinus, in addition to small ones (Fig. 1B). According to shape, characteristic features, and chromatin condensation, the spermatogenesis of $E$. vermiculata can be divided into 5 stages; spermatogonia, primary spermatocytes, secondary spermatocytes, spermatids, and mature sperms. The early developed stages (spermatogonia, spermatocytes) are found near the epidermis of the acinus while the mature stages are found near its centre (Fig. 1B, C).
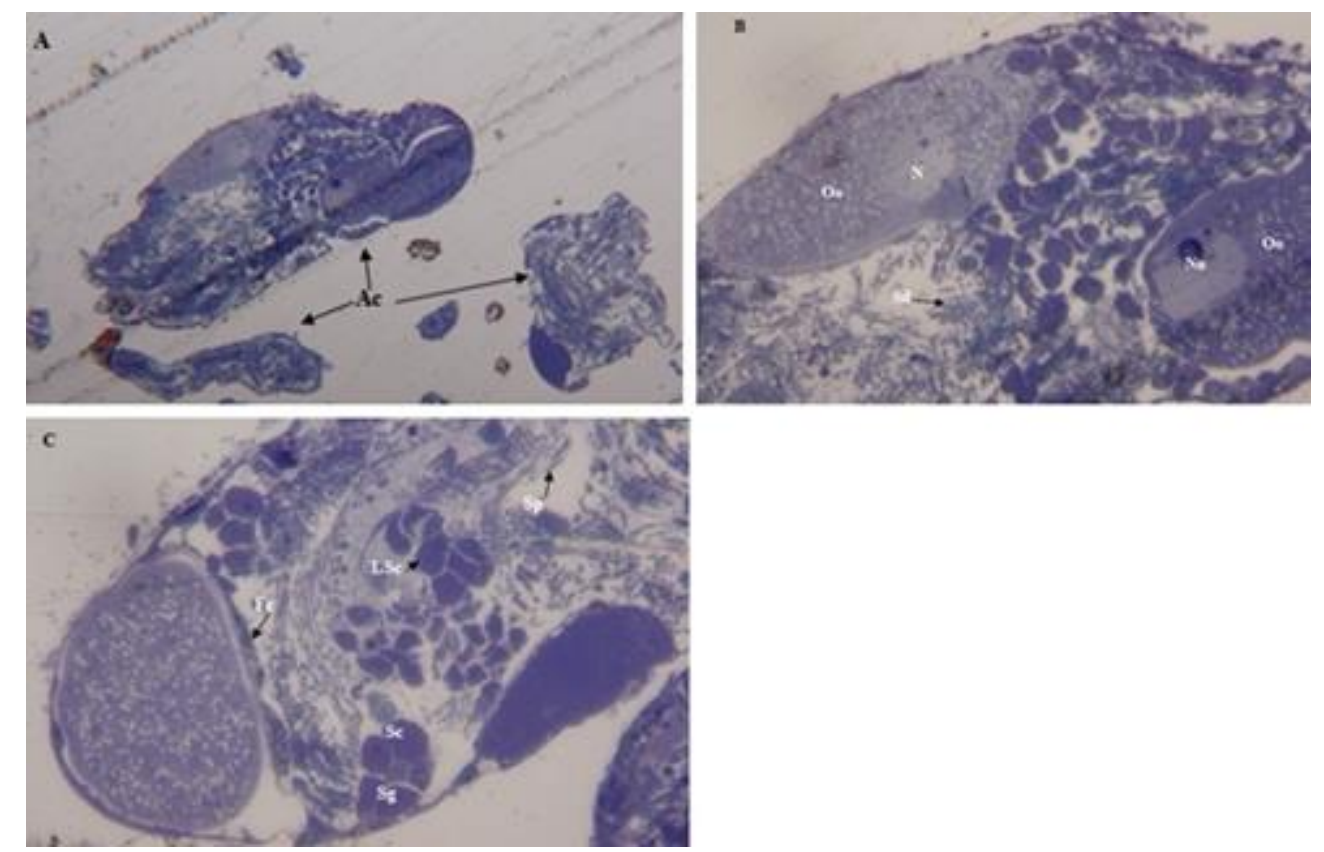

Fig. 1. Semithin sections of E. vermiculata hermaphrodite gland. A- different acini found in the hermaphrodite gland; B- acinus showing two developing oocytes (Oo) with their nuclei and nucleolie and spermatids (Sd); C- acinus showing follicular cells (Fc) separating oocyte from the acinar lumen, different spermatogenic stages, spermatogonia (Sg), spermatocytes (Sc) and sperms (Sp) and presence of luminal Sertoli cells (LSc). Abbreviations: Fc- follicular cells; LSc- luminal Sertoli cells; Oo- oocyte; Scspermatocytes;Sd- spermatids; Sg- spermatogonia; Sp- sperms. A (magnification power 40X) and B- C (magnification power 100X). 


\section{Spermatogonia:}

The spermatogonia are more or less round cells, found in clusters, they measure around $9 \sim 12 \mu \mathrm{m}$ in diameter, they are found near the acinar membrane. Some cells are connected to the cortical Sertoli cells (CSc). The nucleus is an ovoid and contains one or more nucleolus. Some heterochromatin is homogeneously dispersed throughout the nucleus, the nucleoplasm is scattered and occupies a large space compared with the cytoplasm and the nuclear membrane is a visible (Fig.2A).

\section{Primary spermatocytes}

The primary spermatocytes (1ry spermatocytes) have a pear-shaped appearance, their diameter range from 15-19 $\mu \mathrm{m}$. The nucleus occupies most of the cell and is directed towards one side and the other side contains mitochondria. The chromatin forms clumbs and is distributed through the neocleoplasm (Fig.2B).

\section{Secondary spermatocytes}

The 1ry spermatocytes turn into secondary spermatocytes after the first meiotic division, with its chromosomes halving. The secondary spermatocytes are characterized by a smaller size $(14 \sim 18 \mu \mathrm{m}$ in diameter) comparing with the primary spermatocytes and have a bigger semicircular nucleus $(9 \sim 12 \mu \underline{m}$ in diameter). The nucleus was eccentric, circular, lightly stained and their size is larger than those of spermatogonia (Fig.2C). Chromatin is heterogeneously distributed through the nucleus. The organelles are more concentrated on one side of the cell, showing a more polar distribution. Their cytoplasm is abundant and the proportion of nucleoplasm to cytoplasm weaker than in the previous stage. There are many mitochondria in the cytoplasm concentrated in one pole, some mitochondria show a flat saccular shape whereas some mitochondria are still oval saccular (Fig.2C). The Golgi stacks appear in one pole of the cells (Fig.2D).

\section{Spermatids}

Secondary spermatocyte finishes the second meiotic division resulting in spermatid formation. The spermatids were found in the acinar lumen (Fig. 1B). During the process of transformation from spermatid to mature sperm, the spermatid and nucleus start to deform, the chromosome condenses and many changes are observed in this stage. Three phases could be observed for E.vermiculata spermatid on reaching the mature sperm.

\section{A) Early-stage spermatid:}

The spermatid has a cylindrical shape with numerous mitochondria. The nucleus shows a rugby-ball shaped and smaller $(2.06 \mu \mathrm{m} \times 3.2 \mu \mathrm{m}$ in diameter $)$ than that of the secondary spermatocyte. The opposite poles of the nucleus show a dense material that is deposited on both sides of the nuclear envelope. The irregular lateral extension appears in one pole (Fig.3A).

\section{B) Middle-stage spermatid}

The nuclear materials started to condense, the Golgi stacks show inner trans-face that secretes vesicles and mitochondria dispersed in the cytoplasm in addition to many glycogen granules (Fig. 3B). The newly formed axoneme pushes the nuclear envelope that shows an irregular shape at the posterior plaque to form the implantation fossa (Fig. 3C). The mitochondria are collected around the newly formed axoneme. On the other side, the acrosome started to be formed by the presence of a proacrosomal vesicle that seems to be small and round (Fig.3D).

\section{C) Late-stage spermatid}

As spermatids continue to develop, the whole-cell stretches as the axoneme elongates. the nucleus changes from kidney shape into a long tubular shape that occupies the midpiece. The proacrosomal vesicle differentiates further to form an acrosome. The midpiece of the late spermatid is surrounded in some parts with glycogen helix that filled with glycogen granules (Fig.3E,) 

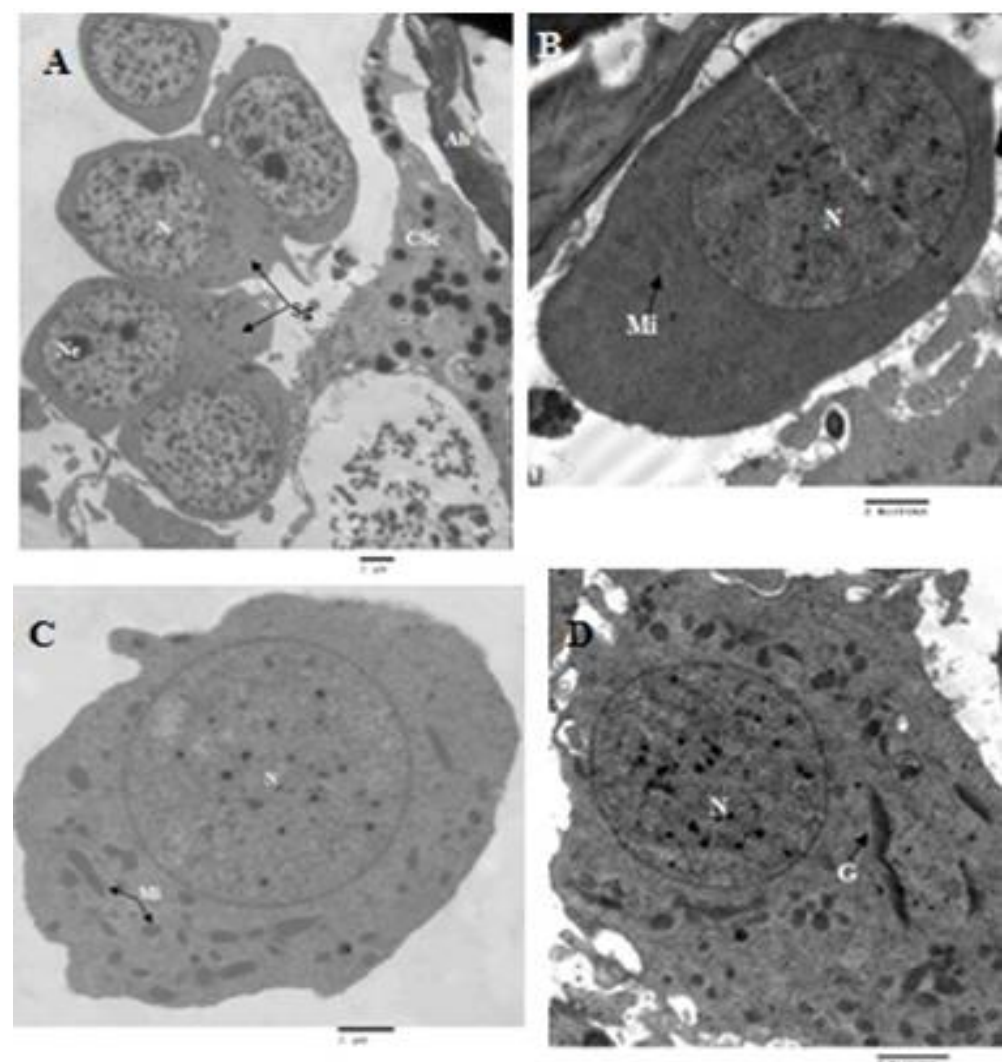

Fig. 2. Transmission electron micrographs of E. vermiculata hermaphrodite gland. A- spermatogonia ( $\mathrm{Sg}$ ) are found in clusters and connected to cortical Sertoli cells $(\mathrm{CSc})$, near the acinar boundary (Ab); B- primary spermatocyte has a large nucleus $(\mathrm{N})$ and multiple mitochondria (Mi); C- secondary spermatocyte contains many oval or flat saccular shape mitochondria (Mi) concentrated in one pole of the cell; D- enlarged part of secondary spermatocyte showing Golgi stacks (G).

Abbreviations: Ab- acinar boundary; CSc- cortical sertoli cells; G- Golgi body; Mi- mitochondria; N- nucleus; Ne- nucleolus; Sgspermatogonia. Scale bar: A-D- $2 \mu \mathrm{m}$ 

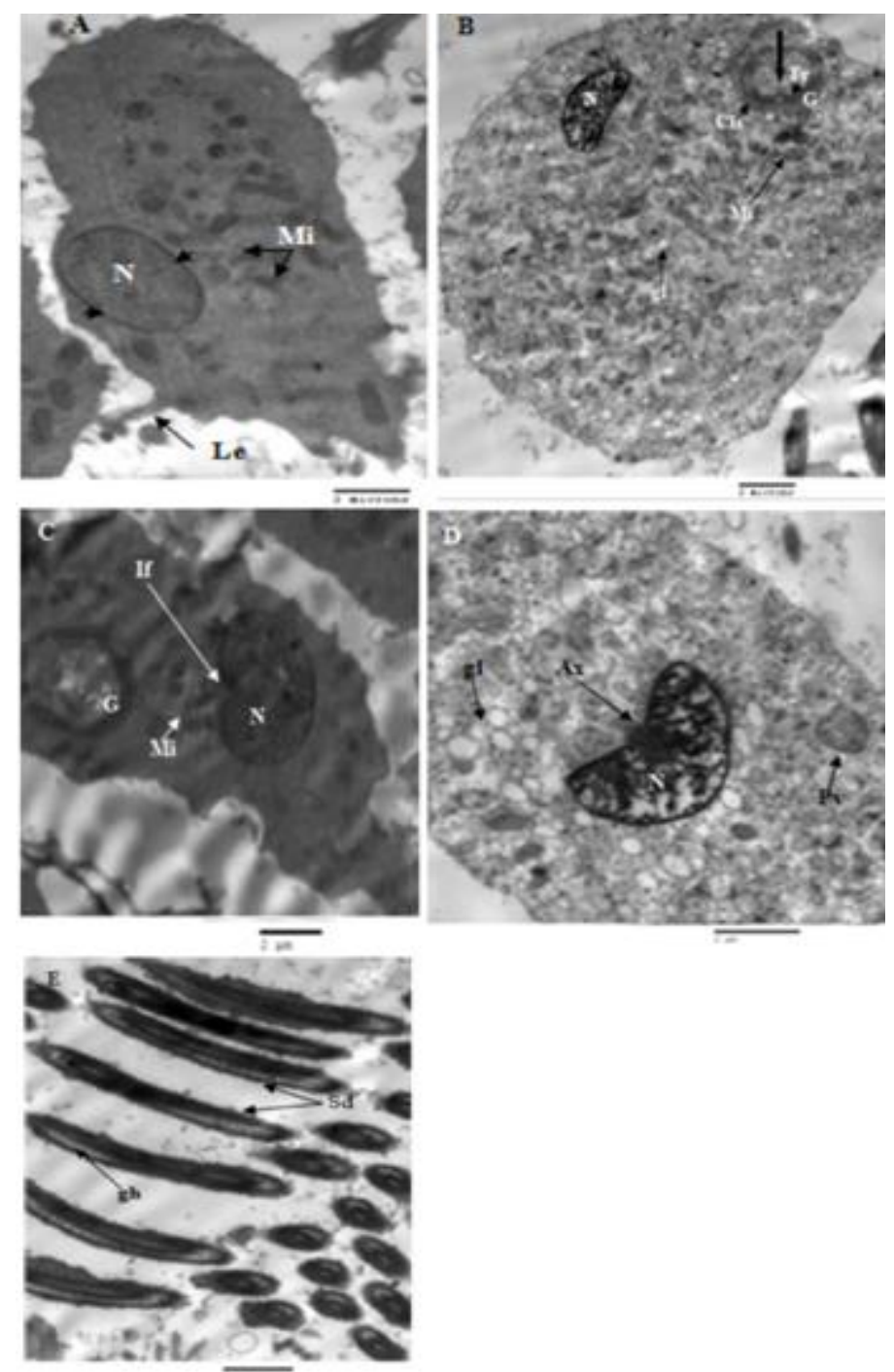

Fig. 3. Transmission electron micrographs of E. vermiculata hermaphrodite gland showing spermatid stage formation. A- early-stage spermatid, showing nucleus (N) located peripherally, the two nuclear membrane opposite sides (arrowheads) deposited dense materials, numerous mitochondria (mi), irregular lateral extension (Le); B- mid-stage spermatid, showing kidney-shaped nucleus (N). Golgi body with its cis-face and trans-face with secretory vesicles (arrow), many glycogen vesicles (gl); C- mid-stage spermatid showing implantation fossa (If) in the nucleus (N) and presence of Golgi body (G) and mitochondria (Mi). concentrated in one pole of the cell; D- mid-stage spermatid showing early formed axoneme deposited in the implanation fossa of the nucleus $(\mathrm{N})$ and presence of many glycogen vesicles $(\mathrm{gl})$, presence of proacrosomal vesicle $(\mathrm{Pv})$; E- late-stage spermatid showing glycogen helix (gh) formed around the axoneme.

Abbreviations: Ax- axoneme; Cis- cis-face of Golgi; gh- glycogen helix; gl-glycogen vesicles; If- implantation fossa; Le- lateral extension; Mi- mitochondria; N- nucleus; Pv- proacrosomal vesicle; Sd- spermatid; Tr- trans-face of Golgi. Scale bar: A-E- $2 \mu \mathrm{m}$

\section{Mature sperm}

The nuclear chromatin becomes completely condensed, surrounded by the plasma membrane, in addition, the nucleus showed elongated form and curvature at its end, near to this end is a centriolar derivative that followed by the axoneme (Fig. 4A). the newly formed sperm with its acrosome is embedded in the luminal Sertoli cell (Fig.4B). The flagellum had irregular lateral fins and glycogen helix with glycogen granules (Fig.4C, D) The end-piece consists of a typical microtubular arrangement of a "9 +2 " axoneme and a plasma membrane (Fig. 4E)

\section{Gonadal somatic cells}

\section{Sertoli cells}

The Sertoli cells showed irregular structure without definite shape or size. They were larger than spermatogenic cells and usually observed throughout the acinar space. Two forms of the sertoli cells could be detected according to their morphology and locations in the acini of the hermaphrodite gland of 
E. vermiculata; cortical Sertoli cells (CSc) and luminal Sertoli cells (LSc) (Fig.5A-D)

The cortical Sertoli cells were found near the cortical compartment of the acini and had numerous electrondense vesicles (Fig.5A). the early spermatogenic stage such as spermatogonia was found near or attached to these forms of Sertoli cells (Fig.5A). their bases were attached to the basal lamina of acini whereas both their lateral and apical regions showed tunneling nanotubes $(\mathrm{Tn})$. The tunneling nanotubes of cortical Sertoli cells had very narrow extensions that connected with neighboring spermatogonia (Fig. $5 \mathrm{~B})$

The luminal Sertoli cells were mostly oval, pearshaped, or bell-shaped and found in the acinar lumen, away from the basal lamina of acini (Fig.5C). The cytoplasm was rich in multiple stacks of Golgi cisternae and cytoplasmic inclusions (Fig. 5D). The spermatogenic stage, mainly spermatids, and newly formed sperms, connected with this kind of Sertoli cells (Fig.5D). The tunneling nanotubes of luminal Sertoli cells were blunt and short and through which the spermatids and sperms were connected.
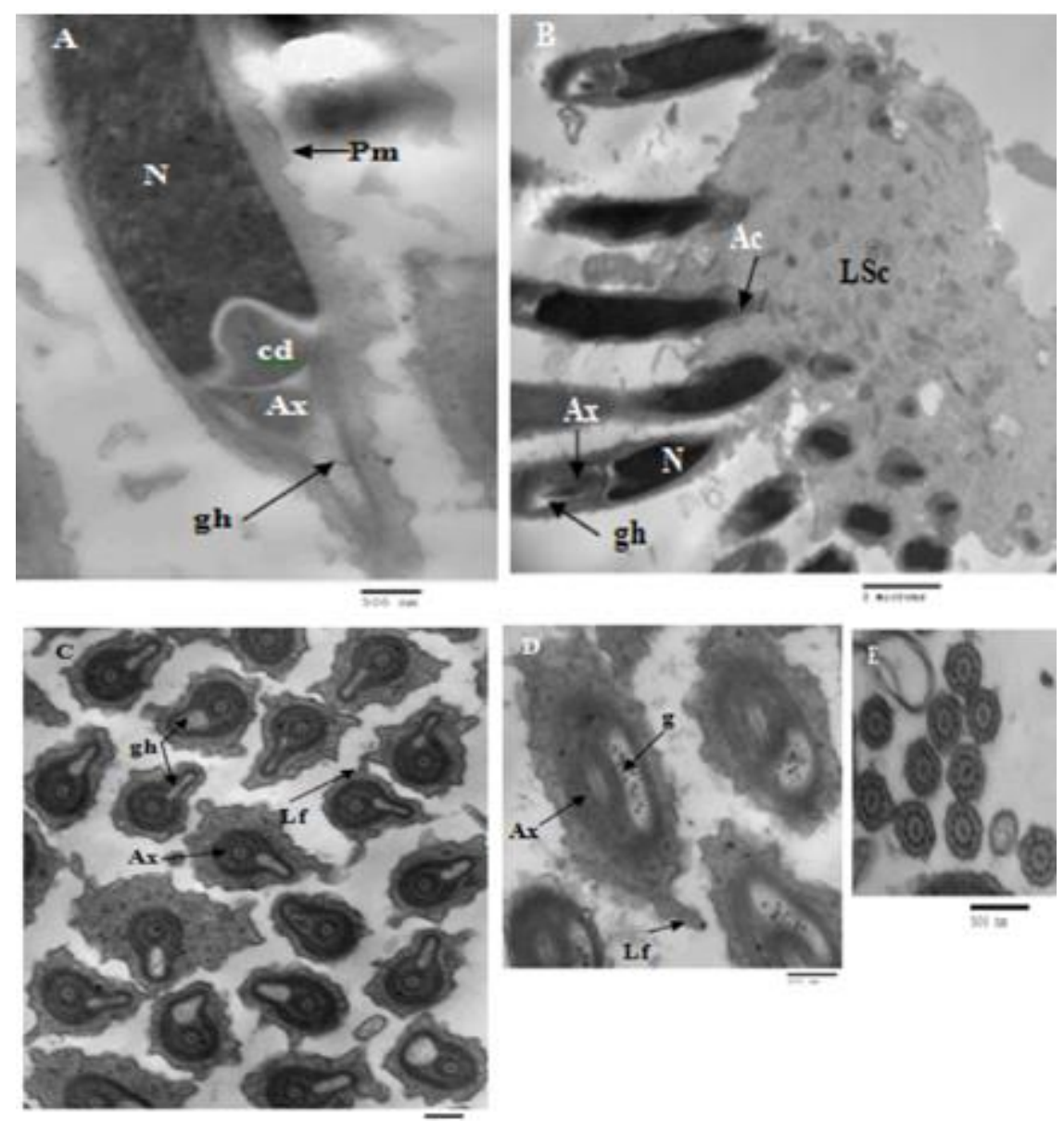

Fig. 4. Transmission electron micrographs of E. vermiculata hermaphrodite gland showing newly formed sperm. A- longitudinal section through mature sperm showing nucleus $(\mathrm{N})$ with a curvature at its end filled with a centriolar derivative (cd) and followed with axoneme (Ax) and glycogen helix (gh); B- newly formed sperm attached through its acrosome (Ac) with luminal Sertoli cell (LSc); C-D- a cross-section of mid-piece of developing sperm showing axoneme(Ax) glycogen helix (gh) containing glycogen granules ( $\mathrm{g}$ ) and presence of lateral fins (Lf); E- transverse section in the tail region of mature sperm showing the axoneme with nine outer microtubule and two central microtubules pattern.

Abbreviations: Ac- acrosome; Ax- axoneme; cd- centriolar derivative; g- glycogen granules; gh- glycogen helix; Lf- lateral fins; LScluminal sertoli cell; N- nucleus. Scale bar: A-500 nm; B-2 $\mu$ m; C- E- 500nm. 


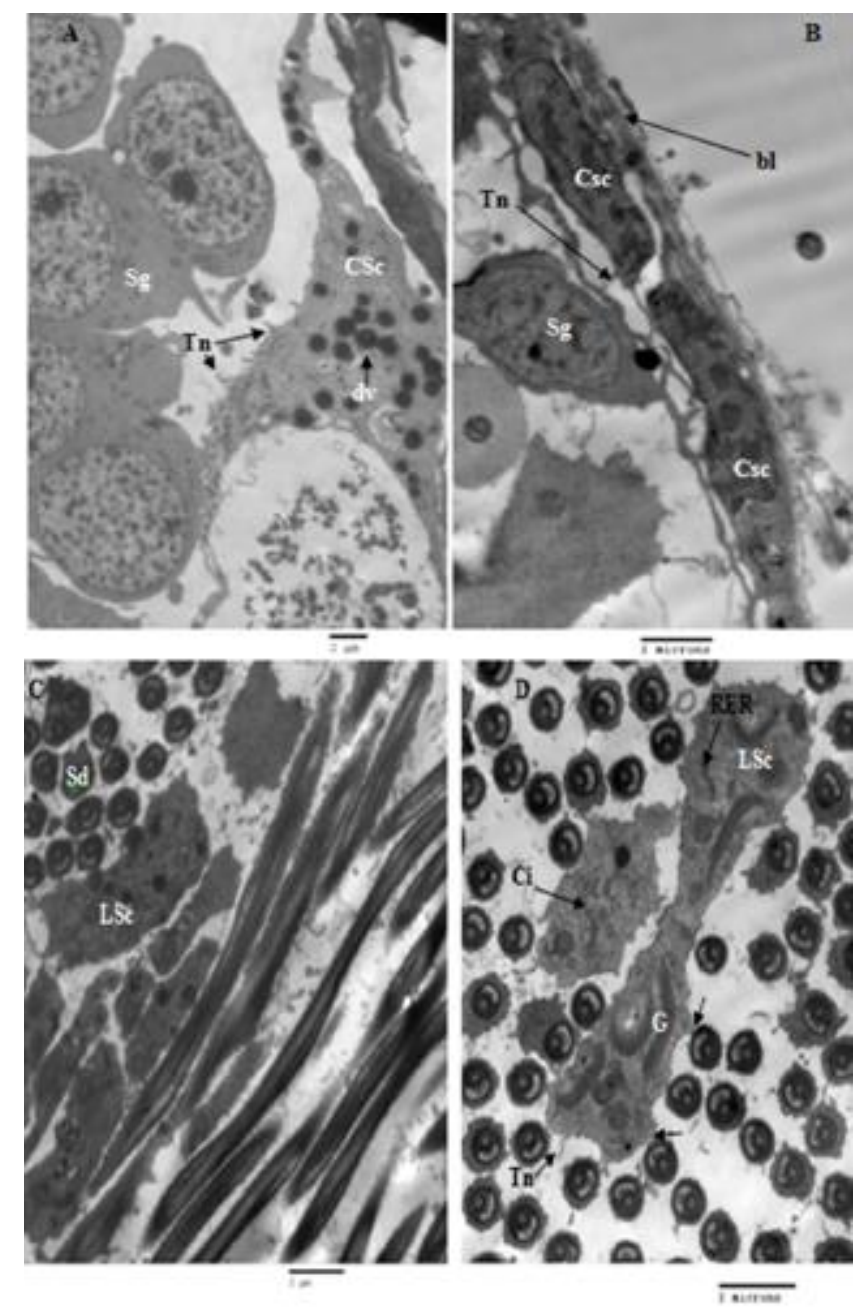

Fig. 5. Transmission electron micrographs of E. vermiculata hermaphrodite gland. A- cortical Sertoli cell (CSc) containing electrondense vesicles and has tunneling nanotubes ( $\mathrm{Tn}$ ) near spermatogonia ( $\mathrm{Sg}$ ); B-cortical Sertoli cell (CSc) located peripherally near basal lamina (bl), tunneling nanotubes (Tn) extend to connect with spermatogonia (Sg); C- luminal Sertoli cells (LSc) found in the acinar lumen near spermatids (Sd); D- luminal Sertoli cell (LSc) cytoplasm has cytoplasmic inclusions (Ci), Golgi body (G) and rough endoplasmic reticulum (RER) and presence of tunneling nanotubes (Tn) the spermatids connected to LSc (arrow). Abbreviations: Blbasal lamina; Ci- cytoplasmic inclusion; CSc- cortical Sertoli cells; dv- dense vesicle; G- Golgi body; LSc- luminal Sertoli cell; RERrough endoplasmic reticulum; Sd- spermatid; Sg- spermatogonia; Tn- tunneling nanotubes. Scale bar: A-D- $2 \mu \mathrm{m}$.

\section{Discussion:}

The present study describes the ultrastructure details of the spermatogenesis (hermaphrodite gland) of Eobania vermiculata. Most features of different stages of gametogenesis in E. vermiculata are similar to another terrestrial (Kulkarni, 1973; Rakshit et al., 2005; Roy et al., 2019) and aquatic pulmonate mollusks (Jong-Brink et al., 1976, 1977; Bing et al., 2008; Silva et al., 2009).

According to their maturation, Successive spermatogenic stages of E. vermiculata were arranged on the basal lamina of acini; spermatids and spermatozoa are usually located near the acinar lumen, while spermatogonia and spermatocytes found near the basal lamina which is similar to other pulmonate molluscs (Hodgson, 1986; Roy et al., 2016, 2018). As in another gastropod spermatogenesis, the morphology of the spermatogonium and spermatocyte shows little changes, the spermatogonium of E. vermiculata is small and cytoplasmic organelle are poorly developed, while the spermatocytes had more cytoplasmic space with many elongate mitochondria than the previous stage. 
The changes in the morphology of spermatid of $E$. vermiculata showed noticeable differences as in other gastropods. Many studies have reported different methods to identify the stages of spermatids in gastropods (Chiva et al., 2011; Roy et al., 2016). There are three ways, firstly spermatid developmental process can be divided into three stages according to the features of acrosome evolution and it was reported in many studies as in Bullacta exarata Philippi, 1849 (Ying et al., 2002), Haliotis asinina Linnaeus, 1758 (Huang et al., 2006), Neptunea cumingii Crosse, 1862 (Hou et al., 2006); Laevicaulis alte Ferussac, 1822 (Roy et al., 2019). Secondly, spermatids can be categorized into five stages according to changes of a nucleus, chromatin, and mitochondria such as in Haliotis diversicolor supertexta Reeve, 1846 (Yan et al., 2006), Trochus pyramis Born, 1778 (Wu et al., 2010). Finally, the spermatid developmental process can be divided into six stages based on the five stages and the morphological features of spermatids, such as in Cipangopaludina chinensis Gray, 1834 (Yan et al., 2004).

In the present work, spermatid development of $E$. vermiculata could be divided into three stages; early, middle- and late-stage spermatid. During the spermatid development, the nucleus changed from round to oval, rugby-ball, and finally to elongated cone at the last stage while the chromatin organized into granular, fibres, and finally became highly condensed. This observation is similar to results obtained by Griffond et al. (1990) who worked on Helix aspersa ovotestis. Chen et al. (2015) found similar results while working on Onchidium struma (Pulmonata: Stylommatophora). Maxwell (1983) reported that the chromatin of primitive sperm nuclei of molluscs is mostly granular and less fibrous. Granular chromatin is the simplest type and occurs in short sperm nuclei, while fibrous patterns can be observed in more elongated nuclei (Chen et al., 2015). Chiva et al. (2011) suggested the type of fertilization is related to the shape changes of the spermatid nucleus and concluded that the nucleus of gastropods is species-specific and it may be a good tool in the classification.

The main function of mitochondria is to provide energy for sperm maturation, to meet the energy demands of spermatogenesis. Moreover, the number of mitochondria increases during the process of spermatogenesis then decreases again which shows essential physiological activities during each stage of spermatogenesis. The primitive sperm mitochondria are distinguished by their vesicular shape while the mitochondria of modified sperm are elongated and others are spiral in shape (Maxwell 1983; Hodgson \& Bernard 1988). Moreover, Yan et al. (2004) explained that the mitochondrial spiralisation may represent the formation process of the mitochondrial sheath of the sperm, thus it saves energy for sperm movement and prepares for the fertilization process. Many studies suggested that few mitochondria within the spermatogonium are scattered throughout the cell, while the number of mitochondria increases significantly at the spermatocyte stage, which is proper for further differentiation, and the mitochondria tend to be located at one end of the cell (Parivar, 1981; Jaramillo et al., 1986; Chen et al., 2015). Similarly, during the sperm development of $E$. vermiculata, the mitochondria are concentrated at one pole of the cell, their number increases at first and decreases finally. In the mid-stage spermatid differentiation, the mitochondria were noticed to be concentrated around the axoneme (implantation fossa). This observation is similar to the changes of mitochondria during the spermatid differentiation of B. exarata (Ying et al., 2002), N. arthritica cumingii (Hou et al., 2006), and O. struma (Chen et al., 2015). It was suggested that there were two developmental methods of the acrosome in gastropod sperm; firstly, it may be originated from many proacrosomal granules in the cytoplasm (Hodgson \& Bernard 1988). According to this theory of spermatogenesis, the proacrosomal vesicles and vesicular bodies cannot be observed even at the spermatid stage and the number of Golgi apparatus is less. Many studies are representative of this type of acrosome formation 
such as the acrosome formation of Haliotis asinina Linnaeus, 1758 (Huang et al. 2006), H. discus Reeve, 1846 (Shiroya 1984), and H. diversicolor aquatilis (Yan et al. 2006).

Secondly, the acrosome is originated from the Golgi apparatus, according to this theory, the acrosomal complex consists of small volume vesicular bodies and a large-volume proacrosomal vesicle is secreted by the Golgi apparatus (Hodgson and Bernard, 1988). This kind was observed in the formation of the acrosomal complex of B. formosae (Ke and Li, 1992), Pomacea maculata Lamarck, 1819 (Zheng and Wu, 2000), and B. exarata (Ying et al., 2002). The acrosome formation of $E$. vermiculata is similar to that found in these species. It was noticed that during the sperm development of $E$. vermiculata, the secretion of Golgi and endoplasmic reticulum is quite active while during the stage of spermatogonium and spermatocyte, there is only a small number of Golgi bodies.

Many controversies prevail with the presence of single or several oocytes in each acinus of different pulmonates. In the present work, it was found that the acini of E. vermiculata contain one or more oocyte and many spermatogenic stages. In agreement with current work, Jong-Brink et al. (1981) found that the aquatic hermaphrodite Lymnea stagnalis acinus had more than one oocyte. In addition, Odiete (1982) reported that Archachatina marginata acinus (Pulmonata: Stylommatophora) had many oocytes in their lumen. In disagreement with the present work, the terrestrial hermaphrodite Achatina fulica possesses only one oocyte in the acinus (Rakshit et al., 2005). In addition, Roy et al. (2019) found that Laevicaulis alte ovotestis contained only one vitellogenic oocyte in each acinus. Moreover, many studies dealing with terrestrial pulmonates reported only a single oocyte per acinus (Tompa, 1984; Boato and Rasotto 1987; Horn et al. 2005; Silva et al. 2009; Roy et al. 2016). The number of oocytes found in each acinus may be based on individual species (Rakshit et al., 2005) or type of habitat (Roy et al.,
2019), as well as the maturity of individual snails and is not probably has taxonomic relatedness.

The hermaphrodite gland of E. vermiculata had two types of gonadal somatic cells; Sertoli cells and follicle cells. Many studies in other pulmonates have reported that the Sertoli cells are spermatogenesisspecific while follicle cells are oogenesis-specific (Eckelbarger and Blades-Eckelbarger, 1989; Rakshit et al., 2005; Roy et al., 2018, 2019). It was found that the Sertoli cells of E. vermiculata had two types, cortical Sertoli cells and Luminal Sertoli cells, which can be distinguished according to their location in the acini and morphological features. Both types of Sertoli cells had several tunneling nanotubes found on their free (luminal) cell surface. The tunneling nanotubes of cortical Sertoli cells were mainly tapering and much longer than those of luminal Sertoli cells which may be responsible for their penetration between developing spermatogenic cells. Many suggestions connected the tunneling nanotubes with developing spermatogenic cells; that might create a thin cytoplasmic bridge between nutritive Sertoli cells and developing spermatogenic cells which do not have direct contact with them (Roy et al., 2019). Moreover, the tunneling nanotubes help to transfer cellular components of Sertoli cells into the developing spermatogenic cells (Rustom et al., 2004). In addition, the Sertoli cells might act as secretory cells (Starke, 1971; Jong- Brink et al., 1977) but there is a doubt about their steroidproducing properties in molluscs (Jong-Brink et al. 1977, 1981; Parivar 1981).

In the current study, the follicle cells were found in the apical surface of the oocyte facing the acinar lumen. This observation is similar to other pulmonate studies that noticed that the follicular layer only covers the apical part of the oocyte ((Jong-Brink et al., 1976; Griffond and Bolzoni- Sungur, 1986). In contrast, Roy et al. (2019) reported that the follicle cells are arranged in a layer and surround the oocyte, which has one end attached to the acinar boundary. Some authors suggested that the envelope of the oocyte in the acinus by the follicle cells is possible 
species-specific (Griffond and Bolzoni- Sungur, 1986, Roy et al., 2016, 2018).

\section{References:}

Bing H.U., Xiao-zhen Y., Xu-gan W.U., Wei-ming T., Yongxu, C. 2008. Development of gonad in different body weights of Onchidium strumall Zoological Research. Vol. 29. P.145-151.

Boato A., Rasotto M.B. 1987. Functional protandry and seasonal reproductive cycle in Solatopupa similis (Bruguière) (Pulmonata Chondrinidae)// Bolletino di zoologia. Vol. 54. P. 119-125.

Chen M.Y., Li J.B., Huang K.C., Ying X.P., Zhang Y.P., Ni X.Y. 2010. Study on the structural characteristics of the reproductive system and reproductive cycle of Onchidium strumal/ Sichuan Journal of Zoology. Vol. 29. P. 426-431.

Chen S.H., Xia L.P., Dahms H.U., Peng X., Ying X. P.2015. The ultrastructural characteristics of spermatogenesis in Onchidium struma (Pulmonata: Onchidiidae) and its functional adaptation// Italian Journal of Zoology. Vol. 82. No. 4. P. 489-498.

Chiva M., Saperas N., Ribes E. 2011. Complex chromatin condensation patterns and nuclear protein transitions during spermiogenesis: Examples from mollusks// Tissue and Cell. Vol. 43. P. 367-376.

Eckelbarger K.J., Blades-Eckelbarger P. 1989. Structure of the ovotestis and evidence for heterosynthetic incorporation of yolk precursors in the oocytes of the nudibranch mollusk, Spurilla neapolitana// Journal of Morphology. Vol. 201. P.105-118.

Franco A., Heude-Berthelin C.,Goux D., Sourdaine P., Mathieu M. 2008. Fine structure of the early stages of spermatogenesis in the pacific oyster, Crassostrea gigas (Mollusca, Bivalvia)// Tissue and Cell. Vol. 40. P.251-260.

Griffond B., Bolozoni-Sungur D. 1986. Stages of oogenesis in the slug, Helix aspersa: cytological, cytochemical and ultrastructural studies// Reproduction, Nutrition and Development. Vol. 26. P. 461-474.
Griffond B., Dadkhah-Teherani Z., Medina A., Bride M. 1990. Ultrastructure of Helix aspersa spermatogenesis: Scanning and transmission electron microscopical contributions// Journal of molluscan studies. Vol.57 P. 277-287.

Heller J. 1990. Longevity in mollusks//Malacologia. Vol. 31. P.259-295.

Heller J. 2001 Life history strategies// G.M. Barker (Ed.). The Biology of Terrestrial Molluscs.UK: CABI Publishing, Wallingford, P. 413-445.

Hermann P.M., Genereux B., Wildering W.C. 2009. Evidence for age-dependent mating strategies in the simultaneous hermaphrodite snail, Lymnaea stagnalis (L.)// Journal of Experimental Biology. Vol. 212. P.3164-3173.

Hodgson A.N., Bernard R.T.F. 1988. A comparison of the structure of the spermatozoa and spermatogenesis of 16 species of Patellid limpet (Mollusca: Gastropoda: Archaeogastropoda)// Journal of Morphology. Vol. 195 P. 205-223.

Hodgson A.N., Healy J.M. 1998. Comparative sperm morphology of the pulmonate limpets Trimusculus costatus, T. reticulatus (Trimusculidae) and Burnupia stenochorias and Ancylus fluviatilis (Ancylidae)// Journal of Molluscan Studies. Vol. 64. P. $447-460$.

Horn A.C.M., Achaval M., Zancan, D.M. 2005. The annual reproductive cycle of the snail Megalobulimus abbreviates (Bequaert, 1948) (Gastropoda, Pulmonata)// Brazilian Journal of Biology. Vol. 65. P. 459-467.

Huang B., Den Z.R., Wang X.B. 2006. Ultrastructural study on spermatogenesis of abalone Haliotis asinina in the China Sea// Oceanologia et Limnologia Sinica. Vol. 37. P. 401-405.

Jong-Brink M., Schot L.P., Schoenmakers H.J., Bergamin Sassen M.J.M. 1981. A biochemical and quantitative electron microscope study on steroidogenesis in ovotestis and digestive gland of the pulmonate snail Lymnaea stagnalis// Gen. Comp. Endocrinol. Vol. 45. P.30-38.

Jong-Brink M., Boer H.H., Hommes T.G., Kodde A. 1977. Spermatogenesis and the role of Sertoli cells in 
the freshwater snail Biomphalaria Glabratal/ Cell Tissue Res. Vol. 181. P.37-58.

Jong-Brink M., De Wit A., Kraal G., Boer H.H. 1976.A light and electron microscope study on oogenesis in the freshwater pulmonate slug Biomphalaria glabrata//Cell and Tissue Research. Vol. 171. P. 195-219

Jaramillo R., Garrido O., Jorquera B. 1986. Ultrastructural analysis of spermiogenesis and sperm morphology in Chorus gigarreus (Lesson, 1879) (Prosobranchia: Muricidae)//Veliger. Vol. 29. P.217225.

Ke C.H., Li F.X. 1992. Ultrastructural studies on spermatogenesis and sperm morphology of Babylonia formosae (Sowerby) (Gastropoda)// Acta Zoologica Sinica. Vol. 38. P. 234-238.

Kulkarni A.B. 1973. The anatomy and histology of the reproductive system of the land slug, Laevicaulis alte// Marathwada University Journal of Sciences. Vol. 12. P. 61-69.

Luchtel D.L. 1972a. Gonadal development and sex determination

in pulmonate mollusks Arion circumscriptus// Zeitschrift für Zellforschung. Vol.130. P. 279-301.

Luchtel D.L. 1972b. Gonadal development and sex determination

in pulmonate mollusks. 1. Arion ater rufus and Deroceras reticulatum// Zeitschrift für Zellforschung. Vol. 130. P. 302-311.

Maxwell W. L. 1983. Spermatogenesis and sperm function // K.G. Adiyodi (ed.). Reproductive biology of invertebrates. Chichester: John Wiley \& Sons. P. 275-319.

Mohamed M.I., Ali R.F. 2011. Reproduction and life history in the two land snails Monacha cartusiana (Müller) and Eobania vermiculata (Müller) (Helicidae: Mollusca) in the laboratory// Animal Biology. Vol. 1. No. 2. P.99-107.

Nanaware S.G., Gonjari G.R. 1989. Studies on the reproductive physiology of molluscs: 6 Histochemical observations on the mucosubstances of spermatheca of marine slug Onchidium verruculatum (Cuv.)//Comparative Physiology and Ecology. Vol. 14. P.149-154.

Odiete W.O. 1982. Fine structural studies on the ovotestis of Archachatina marginata (Swainson) (Pulmonata: Stylommatophora)// Malacologia. Vol. 22. P.137-143.

Parivar K. 1981. Differentiation of the Sertoli cells and post reproductive epithelial cells in the hermaphrodite gland of Arion ater (L.) (Mollusca Pulmonata)// J. Moll. Stud. Vol.46. P.139-147.

Quattrini D., Lanza B. 1964. Osservazioni sulla ovogenesi e sulla spermatogenesi di Vaginulus borellianus (Colosi) Mollusca Gastropoda// Soleolifera. Bolletino di Zoologia. Vol.31. P. 541553.

Rakshit S., Chaki K.K., Sarkar A.K., Misra K.K. 2005. Cytomorphology of ovotestis of a pulmonate mollusc, Achatina fulica// Proc. Zool. Soc. Calcutta.Vol. 58. P. 93-104.

Roy S., Saha S.K., Ghorai N. 2019.The fine structure of gametogenesis and somatic cells in the ovotestis of the terrestrial pulmonate slug, Laevicaulis alte (Férussac, 1822)// Molluscan Research. Vol. 39. No.4. P.1-18.

Roy S., Chaki K.K., Nag T.C., Misra, K.K. 2016. Ultrastructure of ovotestis of young and adult of a pulmonate mollusk, Macrochlamys indica Benson, 1832// Journal of Microscopy and Ultrastructure. Vol. 4. P. 184-194.

Roy S., Chaki K.K., Nag T.C., Misra K.K. 2018.Ultrastructure of gametogenesis in the ovotestis of an estuarine pulmonate slug, Onchidium tigrinum (Stoliczka 1869)// Molluscan Research.

Vol. 38. P. 243-257.

Rustom R., Saffrich R., Markovic I., Walther P., Gerdes H.H. 2004. Nanotubular highways for intercellular organelle transport// Science. Vol. 303. P. 1007-1010.

Shiroya Y.E. 1984. Ultrastructural changes of the "Truncated cone" during the acrosome reaction in Japanese abalone spermatozoa// Development Growth and Differentiation. Vol. 26. P. 25-32. 
Silva R.F., Cubas J.J. M., De Moraes J. 2009. Aspectos histológicos das gônadas hermafroditas de Biomphalaria glabrata e Bradybaena similaris (Mollusca, Gastropoda, Pulmonata)// Papéis Avulsos de Zoologia. Vol. 49. P. 459-466.

Starke F.J. 1971. Electronenmicroskopische untersuchung der zwitergonadenacini von Planorbarius corneus L (Basommatophora)// Z Zellforsch. Vol. 119. P. 483-514.

Tompa A. 1984. Land snails (Stylommatophora)// A.S.M. Saleuddin, K.M. Wilbur (Eds.). The Mollusca. London: Academic Press. P. 47-140.

Wu H.L., Pu L.Y., Feng Y.Q., Dong Y., Liu L., Yan J.X. 2010. Ultrastructure study on spermatogenesis of Trochus pyramis Born// Journal of Tropical Organisms Vol. 11. P. 21-26.

Wang J.Q., Cheng Y.X., Wu X.G., Chen S.L., Wang Z.K., Teng W.M.
2006. Reproductive system and gonadal development of Onchidium strumal/ Chinese Journal of Zoology. Vol. 4. P.19-26.

Yan S.F., Jiang Y.H., Yan Z.L., Chen C.S. 2006. Ultrastructure of spermatogenesis of Haliotis diversicolor aquatilis// Journal of Fishery Sciences of China. Vol. 13. P. 878-884.

Yan Y.Z., Tan Q.K., Chen S.C., Chu L. 2004. An ultrastructural study of the typical spermatogenesis and mature spermatozoon of Cip. angopaludina chinensis Gray// Acta Hydrobiologica Sinica. Vol. 28. P. 45-51.

Ying X.P., Jiang N.C., Yang W.X. 2002. Ultrastructural study on spermatogenesis of Bullacta exarata// Zoological Research.Vol. 23. P.400-404

Zheng S.M., Wu Q. 2000. Ultrastructural studies on spermatogenesis of Pomacea maculata Lamarck// Journal of Southwest China Normal University (Natural Science). Vol. 25. P. 700-703. 